\title{
Origin and Diffusion of the Myotonic Dystrophy Gene in the Saguenay Region (Quebec)
}

\author{
Gérard Bouchard, Raymond Roy, Manon Declos, Jean Mathieu and Kevork Kouladjian
}

\begin{abstract}
A very high prevalence (approximately 1/475 in 1985) of myotonic dystrophy (Steinert disease) is observed in the Saguenay region, which is located in the north-east part of the Province of Quebec. For various reasons, however, the literature on the subject generally associates a high degree of selective disadvantage with this gene, which seems to contradict the Saguenay data. Using a computerized regional population register, we have reconstituted patients' genealogies and family biographies. We have thus been able to study the origin of the gene and to compare the demographic behavior of patients and controls. On the whole, patients seem to be very little disadvantaged compared to controls, in terms of reproduction as well as of geographical and occupational mobility.
\end{abstract}

RÉSUMÉ: Origine et reproduction du gène de la dystrophie myotonique au Saguenay On observe une prévalence très importante (1/475 environ en 1985) de la dystrophie myotonique (ou maladie de Steinert) dans la région du Saguenay, située dans le nord-est de la province de Québec. Pour diverses raisons cependant, la littérature associe généralement à ce gène un désavantage sélectif important, ce qui paraît contredire la prévalence saguenayenne. Utilisant un fichier informatisé de cette population régionale, nous avons reconstitué les biographies familiales et les généalogies des patients. Nous avons ainsi été à même d'étudier l'origine du gène et de comparer les comportements démographiques des patients et de témoins. Dans l'ensemble, les patients paraissent très peu désavantagés par rapport aux autres, du point de vue la reproduction ainsi que de celui de la mobilité géographique et professionnelle.

Can. J. Neurol. Sci. 1989; 16:119-122

The interuniversity Center of Research on Populations (SOREP) began its work on myotonic dystrophy (MyD) (Steinert disease) in the Saguenay Lac St Jean (SLSJ) area in 1979. We here present the principal findings obtained in an extremely schematized form. We have essentially tried to answer two questions. The first one relates to the origin of the gene in the SLSJ area and the second one is about the possible existence of a selective disadvantage that could be associated with this dominant gene.

\section{ORIGIN OF THE GENE}

The first question actually paved the way to three investigations: a) the analysis of the regions of origin of the immigrants who introduced the gene into the SLSJ area; b) the search for a founder effect, that is, to what extent did these immigrants come from the same population of which they represented a sample; and c) the verification of the gene homogeneity, based on analysis of genealogies.

Screening for the disease in the SLSJ region, which SOREP initiated in 1979, has continued ever since almost without any interruption through the Corporation of Research and Action on Hereditary Diseases (CORAMM) and the Chicoutimi Muscular Dystrophy Clinic. In 1983, 455 cases had been identified, and it was possible to group them within 133 kindreds. More than 600 cases are known today, which gave a regional prevalence of approximately $1 / 475$ in 1985 . We then selected the oldest known patient from each kindred. These 133 cases were used as probands for the present research project. The SOREP population register was used for building and analyzing their genealogies. ${ }^{1}$ With the help of an inference method based on a statistical analysis of genealogical filiations, ${ }^{2}$ we tried to identify the probable carriers of the gene among the ancestors of our 133 probands or propositi. Because of biases that will be mentioned later, it is obvious that this procedure does not identify all the carrier ancestors. Moreover, we only retained those with the highest probability $(\geq 0.80)$ of carrying the gene.

\section{Search for a Founder Effect}

Analysis of genealogical inference revealed that at least $80 \%$ of these ancestors came from the neighboring region of Charlevoix (Figure 1). The number of these founders could not be less than 57 (otherwise, it would be impossible to account for all the propositi), and it could easily have reached 77 , a number that might not be considered as a maximum. ${ }^{3}$

\section{Founders' Places of Origin}

It is thus appropriate to speak of a founder effect, especially since in the few SLSJ region ancestries related to older regions

From SOREP, University of Quebec at Chicoutimi (G.B., R.R., K.K.); Statistics Canada, Ottawa (M.D.); SOREP and the Chicoutimi Hospital Muscular Dystrophy Clinic (J.M.)

Reprint requests to: Gérard Bouchard, SOREP, Université du Québec à Chicoutimi, 555 Boulevard de l'Université, Chicoutimi, Québec, Canada G7H 2B1 




Figure l - Location of Saguenay and Charlevoix within the province of Quebec.

Table 1: Distribution of the Founder Couples According to the Number of Propositi to Which They are Related

\begin{tabular}{ccc}
\hline $\begin{array}{c}\text { Number of propositi or } \\
\text { ancestries in which the founder } \\
\text { couple is represented }\end{array}$ & $\begin{array}{c}\text { Number of founders } \\
\text { (or ancestors) }\end{array}$ \\
\hline A.N. & \% \\
\hline 1 & 308 & 65.0 \\
2 & 92 & 19.4 \\
3 & 38 & 8.0 \\
5 & 18 & 3.8 \\
6 & 6 & 1.3 \\
7 & 5 & 1.1 \\
8 & 3 & 0.6 \\
9 & 1 & 0.2 \\
19 & 2 & 0.4 \\
Total & 1 & 0.2 \\
\hline
\end{tabular}

other than Charlevoix, there is at least one filiation connected to Charlevoix through which the gene could have segregated. This effect, however, is not simple in the sense that it cannot be reduced to a very limited immigration of one, two or a few carriers. In fact we are dealing with at least 60 to 75 people whose arrival in the SLSJ area was spread out between the decades of 1842-51 and 1952-61, with a peak between 1842 and 1861. The study of kinship among these 133 propositi reflects the structure of the founder effect. The Phi coefficient is rela- tively low, at 0.001020 . Moreover, the founder couple, that is the most frequent, only appears in 19 of the 133 ancestries (Table 1).

\section{Homogeneity of the Gene}

For obvious clinical and epidemiological reasons, it seemed useful to determine if the 133 probants all carried a copy of the same original gene. The analysis of SLSJ area genealogies did not make it possible to solve this problem, since the number of immigrants carriers was too high. However, the study of their places of origin outside the SLSJ area suggests a common origin in the 17th and 18th centuries. A research project investigating this subject is now being carried out by SOREP.

\section{Search for a Selective Disadvantage}

The question of a selective disadvantage was addressed in the following way. For four particular reasons, it seems that the spreading of the MyD gene might be seriously curtailed. Indeed, according to literature: a) affected men very frequently suffer from diminished fertility, if not total sterility (hypogonadism); b) a significant increase in infant mortality is observed among offspring of affected women; c) the phenotype of the disease makes it more difficult to find a spouse; d) and finally, because of a phenomenon of ante-position or anticipation, the disease would take more and more serious forms from one gen- 
eration to the next. This should theoretically lead to at least a partial extinction of the gene.4-8

At first sight, the large number of cases identified in Saguenay seem to contradict these statements. ${ }^{9}$ With this perspective in mind, we tried to reconstitute the demographic behavior of cases while comparing them to controls. Once again, we took advantage of the computerized Saguenay population register, this time by using family biographies. In order to deal with as long an observation period as possible, we chose the oldest patients among 133 propositi, namely those for whom complete descendance could be reconstituted. This reduced the number to 85. Comparison with a control group, composed of 170 couples, was made for mortality at an early age (neonatal and infant), nuptiality and fertility. The results are summarized as follows.

\section{Mortality at an Early Age}

Almost all the disparities are significant, even when the observation is broken into sub-periods. There is only one exception: for the couples formed between 1930 and 1939, neonatal mortality is greater among the controls than among the cases. For the entire period, the neonatal mortality rate is $69.6 \%$ among the MyD cases, as opposed to $42.4 \%$ among the controls. The infant mortality rates are respectively $131.40 / 00$ and $103.20 / 00$.

\section{Nuptiality}

It is difficult to draw solid conclusions from the analysis of this second variable. Our study dealt with children of couples affected by the disease. Although some of these children were carriers, while others were not, we were unable to distinguish between them. There were also numerous departures consequent to emigration. This left very small numbers to be analyzed for certain sub-periods-precisely those which show the most significant disparities. There seems to exist a tendency among the cases to get married a little less often and a little later than among the controls. But on the whole, conclusions have to be made very cautiously for this variable.

\section{Fertility}

This variable was also hard to deal with because of numerous possible methodological biases. Efforts were made to control for some of them. The first control group displayed the same socio-economic distribution as the cases. Indeed, it is well known that fertility is often very sensitive to this variable. This determined our way of choosing controls: starting with couples affected by the disease, we looked for their married children and picked out their parents-in-law. We therefore postulated that marriage ascertained the social homogeneity. However, by proceeding this way, we obviously favored choosing large families among the control couples: the more children a family had; the more likely it was to be part of our control group. This bias thereby raises some reservation as to the first result, i.e. the total number of births being 9.2 (live births or stillbirths) among the cases and 10.2 among the controls. For this reason, we constructed a second control group, this time by matching the cases and the controls on the basis of the place of residence, year and age at marriage. As with the first control group, we also made sure that these couples had offspring. This time, the average number of births per control couple was established at 9.0.
None of these disparities turned out to be truly significant. The comparison of overall legitimate fertility rates gave analogous results, as well as the calculation of the age of mothers at the birth of their last child. This third fertility indicator nevertheless revealed that, for families who had their last child during the 1920-1929 decade, the average age of the mother was 38.9 for the cases and 41.3 and 39.6, respectively, for the first and second control groups. These differences - which are once again non-significant - suggest that couples affected by the disease began later than others to space out their births or to restrain their number.

Finally, a fourth indicator, which synthesizes the preceding ones, was used. It consists of the average number of children who eventually married, per family (Table 2 ). For reasons given above, the second control group is doubtlessly more reliable than the first one. On the whole, the maximum discrepancy attributable to a selective disadvantage should be located between $5 \%$ and $10 \%$.

\begin{tabular}{|c|c|c|c|}
\hline $\begin{array}{l}\text { Number of children } \\
\text { eventually married }\end{array}$ & $\begin{array}{c}\text { Myotonic } \\
\text { dystrophy } \\
\text { cases }\end{array}$ & $\begin{array}{l}\text { Control } \\
\text { Group } 1\end{array}$ & $\begin{array}{l}\text { Control } \\
\text { Group } 2\end{array}$ \\
\hline 0 & 0 & 0 & 0 \\
\hline 1 & 3 & 1 & 1 \\
\hline 2 & 2 & 2 & 3 \\
\hline 3 & 4 & 3 & 2 \\
\hline 4 & 3 & 5 & 8 \\
\hline 5 & 4 & 10 & 3 \\
\hline 6 & 6 & 6 & 5 \\
\hline 7 & 4 & 10 & 3 \\
\hline 8 & 1 & 8 & 3 \\
\hline 9 & 3 & 8 & 2 \\
\hline 10 & 1 & 3 & 2 \\
\hline 11 & 0 & 4 & 1 \\
\hline 12 & 0 & 2 & 0 \\
\hline 13 & 1 & 3 & 0 \\
\hline Number of families & 32 & 65 & 33 \\
\hline $\bar{x}$ & 5.4 & 6.7 & 5.6 \\
\hline
\end{tabular}

\section{Auxiliary Variables}

Finally, two other variables were tested, i.e. intra-regional geographic mobility and occupational mobility. Once again, no significant disparity could be found. In terms of migration, there are slightly more sedentary or persistent people among the controls. But if only migrants are considered, the controls are slightly more mobile than the cases (an average of 1.28 residence changes as opposed to 1.20). Occupational mobility is slightly higher among the cases (an average of 1.45 changes in occupation, as opposed to 1.18).

\section{Conclusion}

On the whole, couples affected by the disease ( the 85 "propositi") depart very little from the control couples with respect to the demographic and social variables used here. This obviously explains why the MyD gene became so frequent in the Saguenay population. Actually, given the narrow gap observed in the number of married children between the affected couples and the control, it would be necessary to count ten 
generations in order to observe any significant change in the frequency of the gene. ${ }^{10,11}$ It is important, moreover, to recall that our findings are certainly attributable to the fact that the cases we were able to study represented a relatively complete sample of the population expressing the disease. Actually, systematic screening among families in the population, as opposed to an inventory of hospital files, enabled us to take into account minor and even asymptomatic forms of the disease.

One last reservation should be made. We know that some of the ancestors who were carriers of the gene have nonetheless eluded the study; they are the ones who, for one reason or another - perhaps because of a very serious selective disadvantage? - did not have any descendant. By definition, it is impossible to trace them. However, it is believed that the proportion of these ancestors is very low, and perhaps negligible, because of the already high number of founders provided by the Charlevoix region (whose average population was hardly higher than 15,000 inhabitants in the second half of the 19th century) and because of the prevalence of the disease, which is extremely high in SLSJ.

\section{ACKNOWLEDGEMENTS}

The authors express special thanks to B. Lemieux (University of Sherbrooke), C. Laberge and J. Morissette (Laval University), R. Ward, M. Skolnick and T. Bishop (University of Utah), J. Feingold and M.-C. Babron (INSERM, Paris) for the assistance that they provided at one time or another during this research project which began in 1979. Mention should also be made of the contribution of the Chicoutimi Muscular Dystrophy Clinic and the Corporation of Research and Action on Hereditary diseases (CORAMH), which kindly authorized us having access to their data on MyD. L. Bergeron and J. Larouche also contributed to data compilation. The work that led to this article was made possible through the financial assistance of a FCAR Fund
(Quebec), the University of Quebec at Chicoutimi and the Foundation of the University of Quebec at Chicoutimi.

\section{References}

1. Bouchard G, Roy R, Casgrain B. Reconstitution automatique des familles. Le système SOREP. Université du Québec à Chicoutimi, Dossier no. 2, 1985; 2 vol.

2. Kouladjian K. SOREP Document III-C-40. Méthode d'attestation des ancêtres atteints de la dystrophie de Steinert, à l'aide du registre de la population saguenayenne, 1985.

3. Roy R, Declos M, Bouchard G, et al. La reproduction démographique des familles touchées par la dystrophie de Steinert au Saguenay. Genus 1988; 1885-1971.

4. Harper PS. Myotonic dystrophy. W.B. Saunders, Philadelphia 1979.

5. Marcoz JP. Dépistage des hétérozygotes dans une grande famille atteinte de maladie de Steinert aux manifestations cliniques variées. J Gen Hum 1978; 26: 237-274.

6. Tome FMS, Fardeau M. Dystrophie myotonique de Steinert, Encyclopédie Méd. Chir., Paris, Neurologie 1976; 1: 75-84.

7. Penrose LS. The problems of anticipation in pedigrees of dystrophia myotonica. Ann Eugen 1948; 14: 125-132.

8. Robert JM, Pernod J. Etude généalogique de la maladie de Steinert. A Genealogical Study of Steinert Disease. J Gen Hum 1976; 24 : 143-151.

9. Veillette S, Perron M, Desbiens F. La dystrophie myotonique: étude épidémiologique et socio-démographique au SaguenayLac-Saint-Jean. Rapport de recherche. Cegep de Jonquière 1986; 241 pages.

10. Crow JF, Kimura M. An introduction to population genetics theory. New York, Evanston and London: Harper \& Row, Publishers 1970; chapter 5.

11. McCluer JW. The simulation of human fertility; strategy in demographic modeling. In: Mielke JH, Crawford MH, eds. Current Developments in Anthropological Genetics, vol. 1. New York and London: Plenum Press 1980; 111-131. 